\title{
Türkiye'de Bazı Tıbbi ve Aromatik Bitkilerin Üretimi ve Pazarlamasındaki Gelișmelerin Değerlendirilmesi
}

\author{
*Önder Volkan BAYRAKTAR', Görkem ÖZTÜRK², Doğan ARSLAN \\ 'Siirt Üniversitesi, Ziraat Fakültesi, Tarım Ekonomisi Bölümü, Siirt \\ ${ }^{2}$ Bornova Zirai Mücadele Araștırma Enstitüsü, Bornova \\ ${ }^{3}$ Siirt Üniversitesi, Ziraat Fakültesi, Tarla Bitkileri Bölümü, Siirt \\ *Sorumlu yazar e-posta (Corresponding author; e-mail): onder.bayraktar@siirt.edu.tr
}

Geliș Tarihi (Received): 10.09.2017～Kabul Tarihi (Accepted): 17.12.2017

\begin{abstract}
Öz
Tıbbi ve aromatik bitkiler, eski çağlardan beri alternatif tıp, sanayi, kozmetik gibi birçok alanda kullanılmaktadır. Günümüzde sentetik ve kimyasal ilaçların insan sağlığı üzerindeki yan etkileri nedeniyle, șifalı bitkilere olan talep artmıștır. Türkiye, coğrafi yapısı nedeniyle hem genetik çeșitlilik ve endemizm bakımından ve hem de birçok bitkinin gen merkezi konumunda olan bir ülkedir. Ayrıca, Türkiye, șifalı bitkiler ticaretinde dünyadaki en önemli ülkeler arasındadır. Ancak, tıbbi ve aromatik bitkilerin ihracatı konusunda Türkiye'nin yüksek potansiyeline rağmen istenilen seviyeye henüz ulașılmamıștır. Tıbbi bitki ihracatı, 2012 yılından 2016'ya kadar \%46 artıșla 33.6 tondan 49.1 tona yükselmiștir. Aynı zamanda, tıbbi bitki ihracatının değeri, 2012-2016 yılları arasında \%58 artarak 100 milyon ABD dolarından 158 milyon ABD dolarına yükselmiștir. Türkiye'de tıbbi bitki ithalatı ise 2012 ylında 16.9 ton iken 2016 yılında \%50 artarak 25.5 tona ulașmıș durumdadır. 2012 yıında 25 milyon ABD doları olan tıbbi bitki ithalatının değeri, 2016 yılında \%61 oranında artarak 41 milyon ABD dolarına ulașmıștır. 2016 yılında Türkiye'de en çok ihraç edilen șifalı bitkiler kekik, defne yaprağı, kimyon ve anasondur. 2016 yılında ithal edilen Türkiye'nin șifalı bitkileri incelendiğinde çörekotu, karabiber ve zencefil ilk üç sırada yer almaktadır. Bu çalıșmada, seçilen yıllara göre Türkiye'nin ithalat ve inracatında önemli olan bazı tıbbi ve aromatik bitkilerin ihracat, ithalat değer ve miktarları incelenmiș ve bu tıbbi ve aromatik bitkilerin ihracatının artırıması için bazı öneriler getirilmiștir.
\end{abstract}

Anahtar Kelimeler: Tıbbi ve aromatik bitkiler, pazarlama, Türkiye

\section{Evaluation of the Developments in Production and Marketing of Some Medicinal and Aromatic Plants in Turkey}

\section{Abstract}

Medicinal and aromatic plants have been used in many fields such as alternative medicine, industry, cosmetics etc. since ancient times. Nowadays, demand for medicinal plants has increased due to the side effects of synthetic and chemical drugs on human health. Turkey is known as origin of many plants, and has great genetic diversity and endemism because of its geographical position. Turkey is one of the most important medicinal and aromatic plant trader countries of the World. However, despite the high export potential of medicinal plants in Turkey, the desired level has not been reached yet. The amount of exported medicinal and aromatic plants has increased 46\% (from 33.6 tons to 49.1 tons) from 2012 to 2016, value of exported medicinal and aromatic plants increased 58\% (from 100 million USD to 158 million USD) from 2012 to 2016. While amount of imported medicinal and aromatic plants in Turkey were 16.9 tons in 2012, it increased by $50 \%$ in 2016 and reached 25.5 tons. The value of imported medicinal plants, which had been 25 million USD in 2012, increased by $161 \%$ and reached 41 million USD in 2016. The medicinal and aromatic plants most exported from Turkey in 2016 were oregano, bay leaf, cumin, and anise. When imports of Turkey's medicinal plants in 2016 were considered, black cumin, black pepper and ginger were in the top three ranks. In this study, production, amount and value of exports and imports of some essential medicinal and aromatic plants were examined with regard to the selected years and some suggestions were given to increase the export of these medicinal and aromatic plants.

Keywords: Medicinal and aromatic plants, marketing, Turkey 


\section{Giriș}

$\mathrm{T}$ Ibbi ve aromatik bitkiler çok eski zamanlardan bu yana insanlar tarafından baharat, ilaç, sanayi, kozmetik gibi birçok alanda kullanılmaktadır. Günümüzde, sentetik ve kimyasal içerikli ilaçların insan sağlığına yan etkilerinin ortaya çıkması ile tüketicilerin tıbbi bitki tüketim talepleri artıș göstermiștir. Bunun sonucunda tıbbi ve aromatik bitkiler için dünyada hızla büyüyen bir pazar olușmuștur. Uluslararası Ticaret Merkezi verilerine göre, 2010 yılında dünya tıbbi bitki inracat değeri 10.3 milyon ABD dolarıdır. Dünyada tıbbi bitki ihracatında ilk sırayı Tayvan 1.6 milyon $A B D$ doları ile almaktadır. Bunu 1.4 milyon $A B D$ doları ile Singapur, 1.4 milyon ABD doları ile Çin ve 673 bin ABD doları ile Hindistan takip etmektedir.

Türkiye coğrafi yapısı nedeniyle genetik çeșitlilik ve endemizm bakımından zengin bir ülke olmasının yanı sıra birçok bitkinin de gen merkezidir. Türkiye tıbbi bitkiler ticaretinde dünyada en önemli ülkeler arasında yer almaktadır. Türkiye'de, doğadan toplanarak iç ve dıș ticareti yapılan 347 tür bulunmakta ve bunların \%30'unun dıș ticareti yapılmaktadır (Faydalıoğlu ve ark. 2011). Ancak, tıbbi ve aromatik bitkilerin ihracatında Türkiye'nin yüksek potansiyeli olmasına karșın henüz arzu edilen düzeye ulașılamamıștır. Türkiye tıbbi bitki ihracatı 2012 yilında 33.623 ton iken 2016 yilında \%46'lık bir artıș sağlayarak 49.118 tona ulașmıștır. Türkiye tıbbi bitki ihracatı değer olarak incelendiğinde ise; 2012 yılında 100 milyon ABD dolarıyken, 2016 yılında 158 milyon ABD dolarına ulașarak \%58 oranında arttığı saptanmaktadır. Türkiye tıbbi bitki ithalatı 2012 yilında 16.976 ton iken 2016 yilında \%50 oranında artmıș ve 25.449 tona ulașmıștır. 2012 yılında 25 milyon ABD doları olarak gerçekleșen tıbbi bitki ithalatı 2016 yılında 41 milyon ABD dolarına yükselerek \%61'lik bir artıș sağladığı ortaya çıkmaktadır. Türkiye'nin tıbbi bitki ihracatının büyük çoğunluğunun ișlenmemiș ürünlerden olușması, sektörde ülke ekonomisine yeterince katma değer sağlanmamasına neden olmaktadır (Yoğunlu 2011; Metin ve ark. 2012). Türkiye'de doğadan toplanan bitkilerle ilgili yasal düzenlemelerin yeterli olmaması, kültüre alma çalıșmalarını engellemiș ve bunun sonucunda standart ve kaliteli ürün elde etme imkanları oldukça yavaș gelișme göstermiștir (Öztürk ve ark. 2012). Tıbbi ve aromatik bitkilerin ülke ekonomisi için önemli bir kazanç kaynağı olduğu göz önüne alınarak, tıbbi bitki ihracatında zengin bir potansiyele sahip olan Türkiye'nin dünya tıbbi bitki pazarında payının arttııımasını sağlamak amacıyla, sektördeki eksikliklerin giderilmesi gerekmektedir.

Türkiye'de 2016 yılında miktar olarak en çok ihracatı yapılan tıbbi ve aromatik bitkiler; kekik, defne yaprağı, kimyon, anason ve adaçayıdır. Türkiye'nin 2016 yılında ithal ettiği tıbbi ve aromatik bitkiler miktar olarak incelendiğinde, karabiber ilk sırada yer almaktadır. Bunu, sırasıyla çörekotu, zencefil, kimyon, anason, tarçın, defne yaprağı, kekik ve adaçayı takip etmektedir. Bu çalıșmada, Türkiye'nin ithalat ve ihracatında önemli olan kekik, defne yaprağı, kimyon, anason ve adaçayı tıbbi ve aromatik bitkilerinin üretim, ihracat ve ithalat miktarları ile değerleri yıllar itibariyle incelenmiș ve bu bitkilerin ihracatının arttırıması için öneriler getirilmiștir.

\section{Materyal ve Yöntem}

$\mathrm{Bu}$ çalıșmada, Türkiye'nin önemli üretim, inracat ve ithalat tıbbi ve aromatik bitkilerinden olan kekik, defne yaprağı, kimyon, anason ve adaçayı bitkileri ile ilgili gelișmeler, yıllar itibariyle değișimler, üretim alan ve miktarları, ihracat ve ithalat miktar ve değerleri yönünden incelenmiștir. Çalıșmanın ana materyalini Türkiye İstatistik Kurumu, Gıda, Tarım ve Hayvancılık Bakanlığı, Orman ve Su İșleri Bakanlığı, İhracatçı Birlikleri ve FAO'dan elde edilen ham veriler ile, konuyla ilgili yapılan çalıșmalardan elde edilen bilgiler olușturmaktadır. Derlenen ham veriler ,bilgisayar ortamında ülkelere göre dıș ticaret rakamları, Türkiye'ye ait dıș ticaret rakamları ve illere göre üretim alanı ve miktarları bazında düzenlenerek, kekik, kimyon, anason, defne ve adaçayı bitkilerinin Türkiye ve Dünya ticaretinde yıllara göre meydana gelen değișimlerini ortaya koyabilmek amacıyla gerekli karșılaștırmalar yapılmıștır. 


\section{Bulgular ve Tartıșma}

Tıbbi ve aromatik bitkilerin bir kısmının tarımı yapııırken bir kısmı da doğadan toplanarak temin edilmektedir. Türkiye'de kekik, kimyon, anason, rezene, adaçayl, çörek otu, kișniș, çemen, nane, hașhaș, șerbetçiotu gibi bazı bitkilerin tarımı yapılmaktadır. Defne, mahlep, ınlamur, adaçayı ve biberiye gibi bazı bitkiler ise doğadan toplanmaktadır. Türkiye'de iç ve dıș ticareti yapılan bitki türü sayısı 347 adet olup, bunlardan 139 türün ihracatı yapılmaktadır (Özgüven ve ark. 2005). Kültürü yapılan tür sayısı ticareti yapılan 400 kadar bitkinin \%67'si kadardır. Bu nedenle tıbbi ve aromatik bitkilerin kültüre alınması oldukça önemlidir (Arslan ve ark. 2005). Türkiye tıbbi bitki ihracatı yapan 110 ülke arasında 18. sırada bulunmaktadır. Doğu ve Güney Doğu Avrupa ülkeleri arasında ise ihracatta 5. sırada olan Türkiye, ithalatta 8. sıradadır (BAKA, 2012).

Türkiye'de kekik üretimi incelendiğinde; 2012 yılında 11598 ton olan kekik üretimi 2016 yılında 14724 tona ulașmıștır. 2012-2016 yılları arasında son 5 yıl içinde kekik üretim alanında $\% 28.47$, kekik üretim miktarında \%26.95'lik bir artıș olduğu görülmektedir (Çizelge 1).

Türkiye'de kekik üretiminde Denizli ili ilk sırada yer almaktadır. 2016 yılı 14.724 ton olan kekik üretiminin \%85.74'ünü Denizli ili, \%5.62'sini Manisa ili karșılamaktadır. Diğer illerde kekik üretimi oldukça düșüktür (Çizelge 2).

2012 yılı itibarıly kekik ihracat miktarı 13.900 ton ve ihracat değeri 39 milyon 719 bin ABD doları olup, bu rakamlar 2016 yilında

Çizelge 1. Türkiye'de Kekik Üretim Alanı ve Miktarları (2012-2016)

Table 1. Oregano Production Area and Amounts in Turkey (2012-2016)

\begin{tabular}{lcccc}
\hline Yll & Alan (da) & Indeks $(2012=100)$ & Üretim (ton) & İndeks $(2012=100)$ \\
\hline 2012 & 94283 & 100.00 & 11598 & 100.00 \\
2013 & 89137 & 94.54 & 13658 & 117.76 \\
2014 & 92959 & 98.60 & 11752 & 101.33 \\
2015 & 104863 & 111.22 & 12992 & 112.02 \\
2016 & 121127 & 128.47 & 14724 & 126.95 \\
\hline
\end{tabular}

Çizelge 2. Türkiye'de İllere Göre Kekik Üretim Miktarları (2012-2016)

Table 2. Oregano Production Amounts According to Provinces in Turkey (2012-2016)

\begin{tabular}{lcccccc}
\hline \multirow{2}{*}{ il } & 2012 & 2013 & 2014 & 2015 & \multicolumn{2}{c}{2016} \\
\cline { 2 - 7 } & Üretim (ton) & Üretim (ton) & Üretim (ton) & Üretim (ton) & Üretim (ton) & $\%$ \\
\hline Denizli & 10014 & 12183 & 10501 & 10772 & 12624 & 85.74 \\
Manisa & 555 & 566 & 641 & 727 & 828 & 5.62 \\
Muğla & 360 & 352 & 27 & 25 & 48 & 0.33 \\
Ușak & 213 & 205 & 218 & 218 & 262 & 1.78 \\
Hatay & 170 & 170 & 144 & 223 & 187 & 1.27 \\
Aydın & 100 & 31 & 63 & 75 & 165 & 1.12 \\
İzmir & 93 & 43 & 43 & 24 & 24 & 0.16 \\
Antalya & 72 & 70 & 65 & 63 & 32 & 0.22 \\
Balıkesir & 8 & 5 & 5 & - & 2 & 0.01 \\
Isparta & 7 & 6 & 6 & 7 & 5 & 0.03 \\
Afyon & 2 & 25 & 29 & 20 & 20 & 0.14 \\
Karaman & 2 & 2 & 2 & 2 & 2 & 0.01 \\
Osmaniye & 2 & - & - & - & 14 & 0.10 \\
Kütahya & - & - & 8 & 300 & 475 & 3.23 \\
Samsun & - & 13658 & 11752 & 12992 & 36 & 0.24 \\
\hline Toplam & 11598 & & & & 14724 & 100.00 \\
\hline
\end{tabular}


Çizelge 3. Türkiye'nin Kekik İhracat Miktar ve Değerleri (2012-2016)

Table 3. Turkey's Oregano Export Quantities and Values (2012-2016)

\begin{tabular}{cccc}
\hline YIl & $\begin{array}{c}\text { İhracat } \\
\text { Miktarı (ton) }\end{array}$ & $\begin{array}{c}\text { İhracat Değeri } \\
(1000 \$)\end{array}$ & $\begin{array}{c}\text { İhracat } \\
\text { Fiyatı }(\$ / \mathrm{kg})\end{array}$ \\
\hline 2012 & 13900 & 39719 & 2.86 \\
2013 & 14718 & 55976 & 3.80 \\
2014 & 15491 & 59700 & 3.85 \\
2015 & 15153 & 55703 & 3.68 \\
2016 & 17050 & 60380 & 3.54 \\
\hline
\end{tabular}

17.050 ton ve 60 milyon 380 bin ABD dolarına yükselmiștir. 2013 yllında döviz kurunun yükselmesi ile kekik ihracat değeri 56 milyon ABD doları olarak gerçekleșmiștir. Aynı dönemde kekik birim ihracat fiyatı 2012 yılında 2.86 ABD doları/kg iken 2016 yilında 3.54 ABD doları/kg olarak gerçekleșmiștir. Bu dönemde belirgin birihracatartıșınınolduğugörülmektedir (Çizelge 3). Türkiye dünya kekik ihracatında birinci sırada yer almaktadır. İhracatı en çok yapılan ticarette ve uçucu yağ üretiminde kullanılan türler; Origanum onites (bilyalı kekik, Türk kekiği, İzmir kekiği), Origanum vulgare subsp. hirtum [(Sin: Origanum heracleoticum) (Yunan kekiği, İstanbul kekiği)], Origanum minutiflorum [(Sütçüler kekiği, yayla kekiği, toka kekiği) (Endemik)], Origanum majorana [(Sin: Origanum dubium) (Beyaz kekik, Alanya kekiği)], Origanum syriacum var. bevanii (dağ kekiği, Suriye kekiği, İsrail kekiği, Tarsus kekiği), Thymbra spicata ve Thymbra sintenisii (sivri kekik, kara kekik, karabaș kekiği), Satureja cuneifolia (zahter), Coridothymus capitatus (Ispanyol kekiği, Tımari), Thymus kotschyanus (Bitlis kekiği), Satureja hortensis, Satureja montana, Satureja spicigera (Trabzon kekiği), Thymus eigii olarak sıralanabilir. İhraç edilen kekik türleri içerisinde İzmir kekiği (Origanum onites L.) en büyük paya sahiptir (Bașer, 2001; Bașer, 2014; Öztürk ve ark. 2014).

Türkiye'nin kekik ihracatında bașlıca ülkeler ABD ve Almanya'dır. 2016 yılı itibari ile 17050 ton olan Türkiye kekik ihracatında 4092 ton ile ABD \%24'lük payla birinci sırada gelmektedir; 2144 ton ile Almanya \%12.57'lik payla ikinci sırada yer almaktadır. Kekik ihracat fiyatlarına bakıldığında; 2016 yılında Japonya'ya 4.92 ABD doları/kg'dan, Belçika'ya 4.03 ABD doları/kg'dan, Güney Afrika'ya ise 1.86 ABD doları/kg'dan kekik inraç edildiği görülmektedir (Çizelge 4).

2012 yılında 1688 ton karșılığında 3 milyon 342 bin ABD doları kekik ithalatı yapılırken, yıllara göre artıș ve azalıșlar göstererek 2016 yılında 1658 ton karșılı̆̆ında 4 milyon 749 bin ABD doları kekik ithalatı yapılmıștır. Kekik birim ithalat fiyatı 2012 yılında 1.98 ABD doları/ kg iken 2016 yılında 2.86 ABD doları/kg olarak gerçekleșmiștir (Çizelge 5).

Çizelge 4. Türkiye'nin Önemli Ülkelere Göre Kekik İhracat Miktarı ve Değeri (2012-2016)

Table 4. Turkey's Oregano Export Quantities and Value by Major Countries (2012-2016)

\begin{tabular}{lcccccccccc}
\hline & \multicolumn{2}{c}{2012} & \multicolumn{2}{c}{2013} & \multicolumn{2}{c}{2014} & \multicolumn{2}{c}{2015} & \multicolumn{2}{c}{2016} \\
\cline { 2 - 11 } & $\begin{array}{l}\text { Ihracat } \\
\text { Miktarı } \\
\text { (ton) }\end{array}$ & $\begin{array}{c}\text { İhracat } \\
\text { Değeri } \\
(1000 \$)\end{array}$ & $\begin{array}{c}\text { Ihracat } \\
\text { Miktarı } \\
\text { (ton) }\end{array}$ & $\begin{array}{c}\text { Ihracat } \\
\text { Değeri } \\
(1000 \$)\end{array}$ & $\begin{array}{c}\text { ihracat } \\
\text { Miktarı } \\
\text { (ton) }\end{array}$ & $\begin{array}{c}\text { Ihracat } \\
\text { Değeri } \\
(1000 \$)\end{array}$ & $\begin{array}{c}\text { Ihracat } \\
\text { Miktarı } \\
\text { (ton) }\end{array}$ & $\begin{array}{c}\text { Ihracat } \\
\text { Değeri } \\
(1000 \$)\end{array}$ & $\begin{array}{c}\text { Ihracat } \\
\text { Miktarı } \\
\text { (ton) }\end{array}$ & $\begin{array}{c}\text { Ihracat } \\
\text { Değeri } \\
(1000 \$)\end{array}$ \\
\hline ABD & 3489 & 9186 & 3750 & 12817 & 3764 & 12942 & 3641 & 12820 & 4092 & 13090 \\
Almanya & 1404 & 4110 & 1356 & 5387 & 2220 & 7825 & 1796 & 5481 & 2144 & 6677 \\
Belçika & 313 & 1016 & 281 & 1043 & 210 & 822 & 185 & 672 & 114 & 459 \\
Hollanda & 296 & 834 & 247 & 911 & 353 & 1289 & 386 & 1243 & 491 & 1604 \\
Avustralya & 293 & 552 & 226 & 539 & 159 & 377 & 390 & 994 & 183 & 641 \\
Polonya & 290 & 769 & 397 & 1337 & 338 & 1075 & 450 & 1379 & 496 & 1510 \\
İalya & 289 & 565 & 427 & 1042 & 458 & 1174 & 302 & 739 & 343 & 849 \\
Kanada & 259 & 741 & 216 & 985 & 311 & 1269 & 254 & 1054 & 331 & 1252 \\
İspanya & 184 & 426 & 246 & 849 & 143 & 509 & 212 & 649 & 166 & 462 \\
Japonya & 172 & 710 & 150 & 747 & 136 & 658 & 120 & 611 & 143 & 704 \\
Güney Afrika & 151 & 278 & 187 & 423 & 326 & 640 & 239 & 458 & 314 & 584 \\
Rusya & 91 & 193 & 123 & 277 & 98 & 202 & 100 & 205 & 39 & 95 \\
Diğer ülkeler & 6669 & 20339 & 7112 & 29619 & 6975 & 30918 & 7078 & 29398 & 8194 & 32453 \\
Toplam & 13900 & 39719 & 14718 & 55976 & 15491 & 59700 & 15153 & 55703 & 17050 & 60380 \\
\hline
\end{tabular}


Çizelge 5. Türkiye'nin Kekik İthalat Miktar ve Değerleri (2012-2016)

Table 5. Turkey's Oregano Import Quantities and Values (2012-2016)

\begin{tabular}{cccc}
\hline Yıl & $\begin{array}{c}\text { Ithalat } \\
\text { Miktarı (ton) }\end{array}$ & $\begin{array}{c}\text { İthalat Değeri } \\
(1000 \$)\end{array}$ & $\begin{array}{c}\text { ithalat Fiyatı } \\
(\$ / \mathrm{kg})\end{array}$ \\
\hline 2012 & 1688 & 3342 & 1.98 \\
2013 & 1695 & 4304 & 2.54 \\
2014 & 1360 & 3654 & 2.69 \\
2015 & 1348 & 3875 & 2.87 \\
2016 & 1658 & 4749 & 2.86 \\
\hline
\end{tabular}

Türkiye'nin kekik ithalatında en önemli ülkeler Fas, Arnavutluk, Polonya ve Peru'dur. 2016 yllı itibarı ile 1658 ton olan Türkiye kekik ithalatında 493 ton ile Arnavutluk \%29.73'lük payla birinci sırada gelmektedir. Bunu sırasılya; 378 ton ile Fas (\%22.80), 287 ton ile Polonya (\%17.31), 208 ton ile Meksika (\%12.55) takip etmektedir. Kekik ithal edilen ülkelerin ithalat miktar ve değerlerinde yıllar itibarıyla dalgalanmalar olduğu görülmektedir. Ayrıca kekik ithalat fiyatı da ülkelere göre değișmektedir. 2016 ylında Șili'den 4.71 ABD doları/kg'dan, Fransa'dan 4.51 ABD doları/ kg'dan, Mısır'dan 3.56 ABD doları $/ \mathrm{kg}$ 'dan, Meksika'dan 3.24 ABD doları/kg'dan, İtalya'dan 3.14 ABD doları/kg'dan, Polonya'dan 3.01 ABD doları/kg'dan, Fas'tan 2.72 ABD doları/kg'dan ve Arnavutluk'tan 2.54 ABD doları/kg'dan kekik ithalatı gerçekleștirilmiștir (Çizelge 6).

2012 yllında Türkiye'de 226.294 da alanda 13.900 ton olan kimyon üretimi yapilırken 2016 yılında ekiliș alanlarının \%18.81 oranında artmasıyla kimyon üretiminin 18.586 tona yükseldiği görülmüștür (Çizelge 7).

Çizelge 6. Türkiye'nin Önemli Ülkelere Göre Kekik İthalat Miktarı ve Değeri (2012-2016)

Table 6. Turkey's Oregano Import Quantities and Values by Major Countries (2012-2016)

\begin{tabular}{|c|c|c|c|c|c|c|c|c|c|c|}
\hline \multirow[b]{2}{*}{ Ülke } & \multicolumn{2}{|c|}{2012} & \multicolumn{2}{|c|}{2013} & \multicolumn{2}{|c|}{2014} & \multicolumn{2}{|c|}{2015} & \multicolumn{2}{|c|}{2016} \\
\hline & $\begin{array}{c}\text { İthalat } \\
\text { Miktarı } \\
\text { (ton) }\end{array}$ & $\begin{array}{l}\text { İthalat } \\
\text { Değeri } \\
(1000 \$)\end{array}$ & $\begin{array}{l}\text { İthalat } \\
\text { Miktarı } \\
\text { (ton) }\end{array}$ & $\begin{array}{l}\text { İthalat } \\
\text { Değeri } \\
(1000 \$)\end{array}$ & $\begin{array}{c}\text { İthalat } \\
\text { Miktarı } \\
\text { (ton) }\end{array}$ & $\begin{array}{l}\text { İthalat } \\
\text { Değeri } \\
(1000 \$)\end{array}$ & $\begin{array}{c}\text { İthalat } \\
\text { Miktarı } \\
\text { (ton) }\end{array}$ & $\begin{array}{l}\text { Ithalat } \\
\text { Değeri } \\
(1000 \$)\end{array}$ & $\begin{array}{c}\text { İthalat } \\
\text { Miktarı } \\
\text { (ton) }\end{array}$ & $\begin{array}{l}\text { İthalat } \\
\text { Değeri } \\
(1000 \$)\end{array}$ \\
\hline Fas & 869 & 1558 & 696 & 1559 & 330 & 827 & 411 & 1204 & 378 & 1029 \\
\hline Arnavutluk & 574 & 1065 & 480 & 939 & 455 & 1013 & 307 & 637 & 493 & 1254 \\
\hline Polonya & 190 & 504 & 257 & 617 & 249 & 695 & 156 & 421 & 287 & 863 \\
\hline Peru & 17 & 68 & 49 & 220 & 18 & 70 & 18 & 87 & - & - \\
\hline Fransa & 15 & 75 & 33 & 155 & 33 & 151 & 42 & 200 & 78 & 352 \\
\hline Yunanistan & 13 & 42 & 34 & 168 & - & - & - & - & - & - \\
\hline İtalya & 9 & 24 & 14 & 37 & - & - & - & - & 28 & 88 \\
\hline Meksika & - & - & 70 & 330 & 223 & 654 & 382 & 1184 & 208 & 674 \\
\hline Mısır & - & - & 21 & 53 & - & - & 14 & 41 & 68 & 242 \\
\hline Șili & - & - & 16 & 69 & 52 & 244 & 8 & 40 & 7 & 33 \\
\hline Avusturya & - & - & 16 & 115 & - & - & - & - & - & - \\
\hline Diğer ülkeler & 1 & 6 & 9 & 42 & - & - & 10 & 61 & 111 & 214 \\
\hline Toplam & 1688 & 3342 & 1695 & 4304 & 1360 & 3654 & 1348 & 3875 & 1658 & 4749 \\
\hline
\end{tabular}

Çizelge 7. Türkiye'de Kimyon Üretim Alan ve Miktarları (2012-2016)

Table 7. Cumin Production Areas and Amounts in Turkey (2012-2016)

\begin{tabular}{ccccc}
\hline Yıl & Alan (dekar) & İndeks $(2012=100)$ & Üretim (ton) & İndeks $(2012=100)$ \\
\hline 2012 & 226.294 & 100.00 & 13900 & 100.00 \\
2013 & 247.045 & 109.17 & 17050 & 122.66 \\
2014 & 224.421 & 99.17 & 15570 & 112.01 \\
2015 & 270.247 & 119.42 & 16897 & 121.56 \\
2016 & 268.849 & 118.81 & 18586 & 133.71 \\
\hline
\end{tabular}


Çizelge 8. Türkiye'de İllere Göre Kimyon Üretim Miktarları (2012-2016)

Table 8. Cumin Production Quantities by Provinces in Turkey (2012-2016)

\begin{tabular}{|c|c|c|c|c|c|c|}
\hline \multirow{2}{*}{ İI } & \multirow{2}{*}{$\frac{2012}{\text { Üretim (ton) }}$} & \multirow{2}{*}{$\frac{2013}{\text { Üretim (ton) }}$} & \multirow{2}{*}{$\frac{2014}{\text { Üretim (ton) }}$} & \multirow{2}{*}{$\frac{2015}{\text { Üretim (ton) }}$} & \multicolumn{2}{|c|}{2016} \\
\hline & & & & & Üretim (ton) & $\%$ \\
\hline Ankara & 8506 & 10239 & 8301 & 9306 & 11357 & 61.11 \\
\hline Konya & 4174 & 5159 & 6027 & 6462 & 5770 & 31.04 \\
\hline Eskișehir & 689 & 678 & 478 & 384 & 323 & 1.74 \\
\hline Afyon & 318 & 352 & 246 & 180 & 185 & 1.00 \\
\hline Denizli & 115 & 76 & 51 & 43 & 31 & 0.17 \\
\hline Șanlıurfa & 44 & 42 & 9 & 27 & 6 & 0.03 \\
\hline Kırșehir & 34 & 417 & 329 & 391 & 367 & 1.97 \\
\hline Karaman & 12 & 10 & 25 & 25 & 20 & 0.11 \\
\hline Çorum & 4 & 13 & 10 & 7 & 15 & 0.08 \\
\hline Ağrı & 3 & - & - & - & - & - \\
\hline Kilis & 1 & 1 & - & - & - & - \\
\hline Malatya & - & - & - & 1 & - & - \\
\hline Balıkesir & - & - & - & - & - & - \\
\hline Kütahya & - & - & - & 6 & 3 & 0.02 \\
\hline Ușak & - & - & - & - & - & - \\
\hline Burdur & - & - & - & - & 4 & 0.02 \\
\hline Kahramanmaraș & - & - & - & - & 3 & 0.02 \\
\hline Kırıkkale & - & 3 & 2 & 33 & 37 & 0.20 \\
\hline Nevșehir & - & - & 13 & 2 & 2 & 0.01 \\
\hline Kayseri & - & - & 30 & 30 & 450 & 2.42 \\
\hline Sivas & - & 60 & 49 & - & 13 & 0.07 \\
\hline Toplam & 13900 & 17050 & 15570 & 16897 & 18586 & 100.00 \\
\hline
\end{tabular}

Türkiye'nin illere göre kimyon üretim miktarlarının verildiği Çizelge 8 incelendiğinde Ankara ilinin ilk sırada, Konya ilinin ikinci sırada yer aldığı görülmektedir. 2016 yılı 18.586 ton olan kimyon üretiminin \%61.11'ini Ankara ili, \%31.04'ünü ise Konya ili karșılamaktadır (Çizelge 8).

2012 yllında 3.732 ton karșilığında 2.72 \$'dan 10 milyon 167 bin ABD doları kimyon ihraç edilirken, 2016 yllında 8.300 ton karșılığında 2.76 \$'dan 22 milyon 916 bin ABD doları kimyon ihracatı yapılmıștır (Çizelge 9).

2016 yllı itibarı ile 8300 ton olan Türkiye kimyon ihracatında 3089 ton ile Bangladeș (\%37.22) ilk sırada yer almaktadır. Bunu sırasıyla; 1.360 ton ile ABD (\%16.39), 481 ton ile Fransa (\%5.80) takip etmektedir. Kimyon inracat fiyatlarına bakıldığında; 2016 yllında en yüksek 4.12 ABD doları/kg'dan Hollanda'ya, en düșük 1.50 ABD dolar//kg'dan Rusya'ya kimyon inracatı gerçekleștirilmiștir (Çizelge 10).
Çizelge 9. Türkiye'nin Kimyon İhracat Miktar ve Değerleri (2012-2016)

Table 9. Cumin Export Quantities and Values of Turkey (2012-2016)

\begin{tabular}{cccc}
\hline Yıl & $\begin{array}{c}\text { ihracat } \\
\text { Miktarı (ton) }\end{array}$ & $\begin{array}{c}\text { inracat Değeri } \\
(1000 \$)\end{array}$ & $\begin{array}{c}\text { inracat } \\
\text { Fiyatı }(\$ / \mathrm{kg})\end{array}$ \\
\hline 2012 & 3732 & 10167 & 2.72 \\
2013 & 7941 & 20575 & 2.59 \\
2014 & 6011 & 15399 & 2.56 \\
2015 & 3765 & 11134 & 2.96 \\
2016 & 8300 & 22916 & 2.76 \\
\hline
\end{tabular}

2012 yılı itibarı ile kimyon ithalat miktarı 308 ton ve ithalat değeri 859 bin ABD doları olup, bu rakamlar 2016 yılında 2.062 ton ve 5 milyon 527 bin ABD dolarına yükselmiștir. Kimyon birim ithalat fiyatı 2012 yılında 2.79 ABD doları/ kg iken 2016 yilında 2.68 ABD doları/kg'a düșmüștür (Çizelge 11).

Türkiye'nin kimyon ithalatı yaptığı en önemli ülkeler bașta Suriye olmak üzere, Hindistan 
Çizelge 10. Türkiye'nin Önemli Ülkelere Göre Kimyon İhracat Miktarı ve Değeri (2012-2016)

Table 10. Cumin Export Quantities and Values of Turkey by Major Countries (2012-2016)

\begin{tabular}{lcccccccccc}
\hline & \multicolumn{2}{c}{2012} & \multicolumn{2}{c}{2013} & \multicolumn{2}{c}{2014} & \multicolumn{2}{c}{2015} & \multicolumn{2}{c}{2016} \\
\cline { 2 - 10 } Ülke & $\begin{array}{c}\text { Ihracat } \\
\text { Miktarı } \\
\text { (ton) }\end{array}$ & $\begin{array}{c}\text { İhracat } \\
\text { Değeri } \\
(1000 \$)\end{array}$ & $\begin{array}{c}\text { İhracat } \\
\text { Miktarı } \\
\text { (ton) }\end{array}$ & $\begin{array}{c}\text { Ihracat } \\
\text { Değeri } \\
(1000 \$)\end{array}$ & $\begin{array}{c}\text { İhracat } \\
\text { Miktarı } \\
\text { (ton) }\end{array}$ & $\begin{array}{c}\text { İhracat } \\
\text { Değeri } \\
(1000 \$)\end{array}$ & $\begin{array}{c}\text { Ihracat } \\
\text { Miktarı } \\
\text { (ton) }\end{array}$ & $\begin{array}{c}\text { İhracat } \\
\text { Değeri } \\
(1000 \$)\end{array}$ & $\begin{array}{c}\text { ihracat } \\
\text { Miktarı } \\
\text { (ton) }\end{array}$ & $\begin{array}{c}\text { İhracat } \\
\text { Değeri } \\
(1000 \$)\end{array}$ \\
\hline ABD & 1520 & 3250 & 2668 & 6972 & 1503 & 3679 & 764 & 2662 & 1360 & 4508 \\
Bangladeș & 732 & 2353 & 1916 & 4641 & 1980 & 4732 & 1123 & 2846 & 3089 & 7308 \\
Almanya & 188 & 700 & 120 & 416 & 190 & 692 & 403 & 1264 & 411 & 1353 \\
Singapur & 125 & 384 & 560 & 1438 & 1002 & 2568 & 179 & 516 & 175 & 451 \\
Ingiltere & 66 & 190 & 65 & 153 & 23 & 65 & 56 & 199 & 91 & 368 \\
Venezuela & 62 & 203 & 75 & 221 & - & - & - & - & - & - \\
İtalya & 59 & 175 & 2 & 7 & 7 & 24 & 8 & 20 & 2 & 6 \\
Șili & 38 & 126 & - & - & - & - & - & - & - & - \\
Rusya & 32 & 110 & 14 & 42 & 6 & 20 & 7 & 11 & 2 & 3 \\
Hollanda & 26 & 134 & 261 & 767 & 140 & 695 & 141 & 646 & 262 & 1079 \\
Hindistan & 24 & 17 & - & - & - & - & - & - & 132 & 364 \\
Fransa & 16 & 99 & 31 & 209 & 38 & 223 & 171 & 707 & 481 & 1749 \\
Diğer ülkeler & 844 & 2426 & 2229 & 5709 & 1122 & 2701 & 913 & 2263 & 2295 & 5727 \\
\hline Toplam & 3732 & 10167 & 7941 & 20575 & 6011 & 15399 & 3765 & 11134 & 8300 & 22916 \\
\hline
\end{tabular}

Çizelge 11. Türkiye'nin Kimyon İthalat Miktar ve Değerleri (2012-2016)

Table 11. Cumin Import Quantities and Values of Turkey (2012-2016)

\begin{tabular}{cccc}
\hline YIl & $\begin{array}{c}\text { Ithalat } \\
\text { Miktarı (ton) }\end{array}$ & $\begin{array}{c}\text { ithalat Değeri } \\
(1000 \$)\end{array}$ & $\begin{array}{c}\text { ithalat Fiyatı } \\
(\$ / \mathrm{kg})\end{array}$ \\
\hline 2012 & 308 & 859 & 2.79 \\
2013 & 602 & 1662 & 2.76 \\
2014 & 736 & 2032 & 2.76 \\
2015 & 1791 & 4439 & 2.48 \\
2016 & 2062 & 5527 & 2.68 \\
\hline
\end{tabular}

ve Mısır'dır. 2016 yılı itibarı ile 2.062 ton olan Türkiye kimyon ithalatında 2037 ton ile Suriye \%98.91'lik payla birinci sırada gelmektedir (Çizelge 12).
Türkiye'de anason üretimi incelendiğinde 2012 yllında 11.023 ton olan anason üretimi 2016 yllında 9.491 tona düșmüștür. Anason üretim alanı 2012 yılında 194430 da olup \%29.77'lik azalıș göstererek 2016 yılında 136.552 da olmuștur (Çizelge 13).

Türkiye'de anason üretiminde Burdur ilinin ilk sırada, Denizli ilinin ikinci sırada yer aldığı dikkati çekmektedir. 2016 yılı 9.491 ton olan anason üretiminin \%41.38'ini Burdur ili, \%25.15'ini Denizli ili, \%10.01'ini Muğla ili ve \%9.30'unu Antalya karșılamaktadır (Çizelge 14).

Anason Gümrük Tarife İstatistik Pozisyon (GTIP) numaraları altında, Anason-Karaman Kimyonu-Rezene-Ardıç olarak yer almaktadır.

Çizelge 12. Türkiye'nin Önemli Ülkelere Göre Kimyon İthalat Miktarı ve Değeri (2012-2016)

Table 12. Cumin Import Quantities and Values of Turkey by Major Countries (2012-2016)

\begin{tabular}{lcccccccccc}
\hline & \multicolumn{2}{c}{2012} & \multicolumn{2}{c}{2013} & \multicolumn{2}{c}{2014} & \multicolumn{2}{c}{2015} & \multicolumn{2}{c}{2016} \\
\cline { 2 - 10 } Ülke & $\begin{array}{l}\text { Ithalat } \\
\text { Miktarı } \\
\text { (ton) }\end{array}$ & $\begin{array}{c}\text { ithalat } \\
\text { Değeri } \\
(1000 \$)\end{array}$ & $\begin{array}{c}\text { ithalat } \\
\text { Miktarı } \\
\text { (ton) }\end{array}$ & $\begin{array}{c}\text { ithalat } \\
\text { Değeri } \\
(1000 \$)\end{array}$ & $\begin{array}{c}\text { Ithalat } \\
\text { Miktarı } \\
\text { (ton) }\end{array}$ & $\begin{array}{c}\text { Ithalat } \\
\text { Değeri } \\
(1000 \$)\end{array}$ & $\begin{array}{c}\text { ithalat } \\
\text { Miktarı } \\
\text { (ton) }\end{array}$ & $\begin{array}{c}\text { Ithalat } \\
\text { Değeri } \\
(1000 \$)\end{array}$ & $\begin{array}{c}\text { Ithalat } \\
\text { Miktarı } \\
\text { (ton) }\end{array}$ & $\begin{array}{c}\text { Ithalat } \\
\text { Değeri } \\
(1000 \$)\end{array}$ \\
\hline Hindistan & 139 & 334 & 176 & 453 & 55 & 74 & 359 & 510 & 10 & 10 \\
Suriye & 113 & 365 & 348 & 988 & 589 & 1684 & 1407 & 3857 & 2037 & 5488 \\
Mısır & 38 & 100 & 67 & 179 & 74 & 210 & 5 & 5 & 2 & 5 \\
Diğer ülkeler & 18 & 59 & 11 & 42 & 18 & 64 & 20 & 67 & 13 & 24 \\
\hline Toplam & 308 & 859 & 602 & 1662 & 736 & 2032 & 1791 & 4439 & 2062 & 5527 \\
\hline
\end{tabular}


Çizelge 13. Türkiye'de Anason Üretim Alanı ve Miktarları (2012-2016)

Table 13. Anise Production Areas and Amounts in Turkey

\begin{tabular}{ccccc}
\hline Yll & Alan $(\mathrm{da})$ & Indeks $(2012=100)$ & Üretim (ton) & Indeks $(2012=100)$ \\
\hline 2012 & 194.430 & 100.00 & 11023 & 100.00 \\
2013 & 152.431 & 78.40 & 10046 & 91.14 \\
2014 & 140.506 & 72.27 & 9309 & 84.45 \\
2015 & 138.118 & 71.04 & 9050 & 82.10 \\
2016 & 136.552 & 70.23 & 9491 & 86.10 \\
\hline
\end{tabular}

Çizelge 14. Türkiye'de İllere Göre Anason Üretim Miktarları (2012-2016)

Table 14. Amounts of Anise Production by Provinces in Turkey (2012-2016)

\begin{tabular}{lccccc}
\hline \multirow{2}{*}{ il } & 2012 & 2013 & 2014 & 2015 & 2016 \\
\cline { 2 - 5 } Burdur & Üretim (ton) & Üretim (ton) & Üretim (ton) & Üretim (ton) & Üretim (ton) \\
Denizli & 4268 & 4246 & 4021 & 3777 & 3927 \\
Muğla & 3171 & 2055 & 1998 & 2004 & 2387 \\
Antalya & 1201 & 800 & 900 & 900 & 950 \\
Afyon & 995 & 1130 & 930 & 940 & 883 \\
Bursa & 475 & 620 & 554 & 574 & 540 \\
Balıkesir & 444 & 483 & 440 & 423 & 429 \\
Konya & 260 & 230 & 184 & 136 & 85 \\
İzmir & 188 & 221 & 183 & 224 & 204 \\
Kütahya & 21 & 20 & 12 & 7 & 5 \\
Ușak & - & - & - & - & 3 \\
Eskișehir & - & - & - & - & 27 \\
Ankara & - & 210 & 84 & 63 & 49 \\
Sivas & - & 15 & 3 & 2 & 2 \\
\hline Toplam & - & 16 & - & - & - \\
\hline
\end{tabular}

2012 yılı itibarı ile anason ihracat miktarı 1.838 ton ve ihracat değeri 6 milyon 323 bin ABD doları olup, bu rakamlar 2016 yılında 3610 ton ve 12 milyon 629 bin ABD dolarına yükselmiștir. Aynı dönemde anason birim ihracat fiyatı 2012 yılında 3.44 ABD doları/kg iken 2016 yılında 3.50 ABD doları/kg olarak gerçekleșmiștir (Çizelge 15).

Türkiye'nin 2012-2016 döneminde önemli ülkelere göre anason ihracatı Çizelge 16'da verilmiștir. 2016 yılı itibarı ile 3610 ton olan Türkiye anason ihracatında 1.485 ton ile ABD \%41.14'lük payla birinci sırada gelmektedir. 531 ton ile Almanya \%14.71'lik payla ikinci sırada, 333 ton ile Hollanda \%9.22'lik payla üçüncü sırada yer almaktadır. Anason ihracat fiyatlarına bakıldığında; 2016 yılında Almanya'ya 4.71 ABD doları/kg'dan, Hollanda'ya 4.05 ABD doları/
Çizelge 15. Türkiye'nin Anason İhracat Miktar ve Değerleri (2012-2016)

Table 15. Turkey's Anise Export Quantities and Values (2012-2016)

\begin{tabular}{cccc}
\hline Yıl & $\begin{array}{c}\text { Ihracat } \\
\text { Miktarı } \\
\text { (ton) }\end{array}$ & $\begin{array}{c}\text { İhracat } \\
\text { Değeri } \\
(1000 \$)\end{array}$ & $\begin{array}{c}\text { Ihracat } \\
\text { Fiyatı }(\$ / \\
\mathrm{kg})\end{array}$ \\
\hline 2012 & 1838 & 6323 & 3.44 \\
2013 & 1944 & 7903 & 4.06 \\
2014 & 3809 & 14186 & 3.72 \\
2015 & 3251 & 11589 & 3.57 \\
2016 & 3610 & 12629 & 3.50 \\
\hline
\end{tabular}

kg'dan ve ABD'ye ise 3.27 ABD doları/kg'dan anason ihraç edildiği görülmektedir (Çizelge 16).

2012 yılında 1750 ton karșılığında 3 milyon 562 bin ABD doları anason ithalatı yapılırken, yıllara göre artıș ve azalıșlar göstererek 2016 yılında 1889 ton karșılığında 4 milyon 258 bin 
Çizelge 16. Türkiye'nin Önemli Ülkelere Göre Anason İhracat Miktarı ve Değeri (2012-2016)

Table 16. Anise Export Quantities and Values of Turkey by Major Countries (2012-2016)

\begin{tabular}{lcccccccccc}
\hline & \multicolumn{2}{c}{2012} & \multicolumn{2}{c}{2013} & \multicolumn{2}{c}{2014} & \multicolumn{2}{c}{2015} & \multicolumn{2}{c}{2016} \\
\cline { 2 - 10 } Ülke & $\begin{array}{l}\text { Ihracat } \\
\text { Miktarı } \\
\text { (ton) }\end{array}$ & $\begin{array}{c}\text { İhracat } \\
\text { Değeri } \\
(1000 \$)\end{array}$ & $\begin{array}{c}\text { Ihracat } \\
\text { Miktarı } \\
\text { (ton) }\end{array}$ & $\begin{array}{c}\text { Ihracat } \\
\text { Değeri } \\
(1000 \$)\end{array}$ & $\begin{array}{c}\text { Ihracat } \\
\text { Miktarı } \\
\text { (ton) }\end{array}$ & $\begin{array}{c}\text { ihracat } \\
\text { Değeri } \\
(1000 \$)\end{array}$ & $\begin{array}{c}\text { ihracat } \\
\text { Miktarı } \\
\text { (ton) }\end{array}$ & $\begin{array}{c}\text { Ihracat } \\
\text { Değeri } \\
(1000 \$)\end{array}$ & $\begin{array}{c}\text { Ihracat } \\
\text { Miktarı } \\
\text { (ton) }\end{array}$ & $\begin{array}{c}\text { Ihracat } \\
\text { Değeri } \\
(1000 \$)\end{array}$ \\
\hline ABD & 402 & 1248 & 423 & 1491 & 900 & 3485 & 724 & 2596 & 1485 & 4850 \\
Almanya & 407 & 1504 & 472 & 2177 & 586 & 2942 & 545 & 2217 & 531 & 2499 \\
Hollanda & 354 & 1418 & 278 & 1261 & 248 & 1120 & 448 & 1751 & 333 & 1347 \\
Brezilya & 125 & 520 & 152 & 657 & 423 & 1359 & 371 & 1132 & 130 & 375 \\
İtalya & 71 & 197 & 60 & 284 & 58 & 216 & 64 & 243 & 74 & 237 \\
Fransa & 38 & 96 & 19 & 92 & 33 & 121 & 40 & 146 & 62 & 205 \\
Hindistan & 43 & 175 & 40 & 210 & 13 & 45 & 13 & 41 & 58 & 184 \\
İsviçre & 64 & 147 & 97 & 238 & 84 & 239 & 20 & 56 & 48 & 130 \\
İspanya & 90 & 231 & 10 & 25 & 65 & 243 & 58 & 177 & 36 & 111 \\
Yunanistan & 16 & 60 & 23 & 85 & 47 & 148 & 34 & 97 & 35 & 103 \\
Japonya & 7 & 41 & 17 & 83 & 1 & 5 & 22 & 77 & 7 & 25 \\
D. ülkeler & 221 & 686 & 353 & 1300 & 1351 & 4263 & 912 & 3473 & 811 & 2563 \\
\hline Toplam & 1838 & 6323 & 1944 & 7903 & 3809 & 14186 & 3251 & 11589 & 3610 & 12629 \\
\hline
\end{tabular}

ABD doları anason ithalatı yapılmıștır. Anason birim ithalat fiyatı 2012 yılında 2.04 ABD doları/ kg iken 2016 yılında 2.25 ABD doları/kg olarak gerçekleșmiștir (Çizelge 17).

Çizelge 17. Türkiye'nin Anason İthalat Miktar ve Değerleri (2012-2016)

Table 17. Turkey's Anise Import Quantities and Values (2012-2016)

\begin{tabular}{cccc}
\hline Yll & $\begin{array}{c}\text { ithalat } \\
\text { Miktarı } \\
\text { (ton) }\end{array}$ & $\begin{array}{c}\text { ithalat } \\
\text { Değeri } \\
(1000 \$)\end{array}$ & $\begin{array}{c}\text { Ithalat } \\
\text { Fiyatı }(\$ / \\
\mathrm{kg})\end{array}$ \\
\hline 2012 & 1750 & 3562 & 2.04 \\
2013 & 775 & 1966 & 2.54 \\
2014 & 1345 & 3972 & 2.95 \\
2015 & 1041 & 2594 & 2.49 \\
2016 & 1889 & 4258 & 2.25 \\
\hline
\end{tabular}

Türkiye'nin anason ithalatında en önemli ülke Suriye'dir. 2016 yılı itibarı ile 1889 ton olan Türkiye anason ithalatında 1667 ton ile Suriye \%88.46'lık payla birinci sırada gelmektedir. 2016 yılında Suriye'den 2.34 ABD doları/kg'dan anason ithalatı gerçekleștirilmiștir (Çizelge 18).

2012 yılında 12351 ton olan defne yaprağı üretimi 2015 yılında \%75.16 oranında artarak 21634 tona yükselmiștir (Çizelge 19).

Türkiye dünyada en önemli defne yaprağı ihracatçısı ülkedir ve dünya defne yaprağı gereksiniminin yaklașı \%90'ını karșılamaktadır (Özgüven ve ark. 2005). 2012 yılı itibarı ile defne yaprağı ihracat miktarı 10.483 ton ve ihracat değeri 29 milyon 951

Çizelge 18. Türkiye'nin Önemli Ülkelere Göre Anason İthalat Miktarı ve Değeri (2012-2016)

Table 18. Turkey's Import Quantities and Values of Anise by Major Countries (2012-2016)

\begin{tabular}{lcccccccccc}
\hline & \multicolumn{2}{c}{2012} & \multicolumn{2}{c}{2013} & \multicolumn{2}{c}{2014} & \multicolumn{2}{c}{2015} & \multicolumn{2}{c}{2016} \\
\cline { 2 - 10 } Ülke & $\begin{array}{c}\text { Ithalat } \\
\text { Miktarı } \\
\text { (ton) }\end{array}$ & $\begin{array}{c}\text { İthalat } \\
\text { Değeri } \\
(1000 \$)\end{array}$ & $\begin{array}{c}\text { Ithalat } \\
\text { Miktarı } \\
\text { (ton) }\end{array}$ & $\begin{array}{c}\text { Ithalat } \\
\text { Değeri } \\
(1000 \$)\end{array}$ & $\begin{array}{c}\text { Ithalat } \\
\text { Miktarı } \\
\text { (ton) }\end{array}$ & $\begin{array}{c}\text { Ithalat } \\
\text { Değeri } \\
(1000 \$)\end{array}$ & $\begin{array}{c}\text { Ithalat } \\
\text { Miktarı } \\
\text { (ton) }\end{array}$ & $\begin{array}{c}\text { Ithalat } \\
\text { Değeri } \\
(1000 \$)\end{array}$ & $\begin{array}{c}\text { İthalat } \\
\text { Miktarı } \\
\text { (ton) }\end{array}$ & $\begin{array}{c}\text { Itthalat } \\
\text { Değeri } \\
(1000 \$)\end{array}$ \\
\hline Suriye & 1470 & 3039 & 575 & 1419 & 944 & 2935 & 445 & 1150 & 1667 & 3894 \\
Mısır & 58 & 99 & 63 & 119 & 167 & 421 & 199 & 437 & 154 & 219 \\
Sırbistan & 138 & 184 & 100 & 199 & 156 & 289 & 215 & 385 & 40 & 72 \\
Makedonya & 45 & 82 & 24 & 58 & 49 & 126 & 138 & 408 & 24 & 58 \\
Almanya & 23 & 150 & 5 & 137 & 21 & 190 & 26 & 136 & - & - \\
Çin & 14 & 6 & 2 & 4 & 6 & 5 & 0.4 & 1 & - & - \\
Diğer ülkeler & 1 & 1 & 6 & 30 & 2 & 6 & 18 & 77 & 4 & 14 \\
\hline Toplam & 1750 & 3562 & 775 & 1966 & 1345 & 3972 & 1041 & 2594 & 1889 & 4258 \\
\hline
\end{tabular}


Çizelge 19. Türkiye'de Defne Yaprağı Üretim Miktarları (2012-2015)

Table 19. Bay Leaf Production Amounts in Turkey (2012-2015)

\begin{tabular}{ccc}
\hline Yıl & Üretim (ton) & İndeks $(2012=100)$ \\
\hline 2012 & 12351 & 100.00 \\
2013 & 15178 & 122.89 \\
2014 & 15581 & 126.15 \\
2015 & 21634 & 175.16 \\
\hline
\end{tabular}

bin ABD doları olup, bu rakamlar 2016 yilında 14.073 ton ve 40 milyon 101 bin ABD dolarına yükselmiștir. Aynı dönemde defne yaprağı birim ihracat fiyatı 2012 yilında 2.86 ABD doları/kg iken 2016 yllında 2.85 ABD doları/kg olarak gerçekleșmiștir (Çizelge 20).

Defne yaprağı ihracatında Vietnam, ABD, Brezilya ve Polonya'nın önemli ülkeler olduğu görülmektedir. 2016 yılı itibarı ile 14.073 ton olan Türkiye defne yaprağı ihracatının \%61.64'ü Vietnam'a, \%5.24'ü ABD'ye, \%2.93'ü Brezilya'ya \%2.48'i Polonya'ya ve
Çizelge 20. Türkiye'nin Defne Yaprağı İhracat Miktar ve Değerleri (2012-2016)

Table 20. Turkey's Bay Leaf Export Quantities and Values (2012-2016)

\begin{tabular}{cccc}
\hline Yıl & $\begin{array}{c}\text { İracat } \\
\text { Miktarı } \\
\text { (ton) }\end{array}$ & $\begin{array}{c}\text { İracat } \\
\text { Değeri } \\
(1000 \$)\end{array}$ & $\begin{array}{c}\text { İhracat } \\
\text { Fiyatı } \\
(\$ / \mathrm{kg})\end{array}$ \\
\hline 2012 & 10483 & 29951 & 2.86 \\
2013 & 10677 & 32231 & 3.02 \\
2014 & 12256 & 35762 & 2.92 \\
2015 & 12724 & 35831 & 2.82 \\
2016 & 14073 & 40101 & 2.85 \\
\hline
\end{tabular}

\%2.40'ı Almanya'ya ihraç edilmiștir. Defne yaprağı ihracat fiyatlarına bakıldığında; 2016 yilında Polonya'ya 4.74, ABD'ye 3.93 ve Vietnam'a $2.15 \mathrm{ABD}$ doları/kg'dan ihraç edildiği görülmektedir (Çizelge 21).

Defne yaprağı ithalat miktar ve değerlerinde yıllara göre önemli dalgalanmalar olduğu dikkati çekmektedir. 2012 yılında 716 ton karșılığında 1.27 milyon $A B D$ doları olarak gerçekleșen

Çizelge 21. Türkiye'nin Önemli Ülkelere Göre Defne Yaprağı İhracat Miktarı ve Değeri (2012-2016) Table 21. Export Quantities and Values of Turkey's Bay Leaf by Major Countries (2012-2016)

\begin{tabular}{|c|c|c|c|c|c|c|c|c|c|c|}
\hline \multirow[b]{2}{*}{ Ülke } & \multicolumn{2}{|c|}{2012} & \multicolumn{2}{|c|}{2013} & \multicolumn{2}{|c|}{2014} & \multicolumn{2}{|c|}{2015} & \multicolumn{2}{|c|}{2016} \\
\hline & $\begin{array}{c}\text { İhracat } \\
\text { Miktarı } \\
\text { (ton) }\end{array}$ & $\begin{array}{l}\text { İhracat } \\
\text { Değeri } \\
(1000 \$)\end{array}$ & $\begin{array}{l}\text { İhracat } \\
\text { Miktarı } \\
\text { (ton) }\end{array}$ & $\begin{array}{l}\text { İhracat } \\
\text { Değeri } \\
(1000 \$)\end{array}$ & $\begin{array}{c}\text { İhracat } \\
\text { Miktarı } \\
\text { (ton) }\end{array}$ & $\begin{array}{l}\text { İhracat } \\
\text { Değeri } \\
(1000 \$)\end{array}$ & $\begin{array}{c}\text { İhracat } \\
\text { Miktarı } \\
\text { (ton) }\end{array}$ & $\begin{array}{l}\text { İhracat } \\
\text { Değeri } \\
(1000 \$)\end{array}$ & $\begin{array}{l}\text { İhracat } \\
\text { Miktarı } \\
\text { (ton) }\end{array}$ & $\begin{array}{l}\text { İhracat } \\
\text { Değeri } \\
\text { (1000\$) }\end{array}$ \\
\hline Vietnam & 5089 & 10441 & 5217 & 11241 & 6815 & 14276 & 7265 & 15481 & 8674 & 18642 \\
\hline$A B D$ & 586 & 1746 & 597 & 1919 & 623 & 1997 & 492 & 1752 & 738 & 2900 \\
\hline Brezilya & 460 & 1357 & 430 & 1314 & 489 & 1348 & 513 & 1400 & 413 & 1110 \\
\hline Polonya & 349 & 1654 & 432 & 2649 & 613 & 3537 & 524 & 2538 & 349 & 1654 \\
\hline Almanya & 302 & 1552 & 414 & 2008 & 314 & 1350 & 210 & 955 & 338 & 1277 \\
\hline Japonya & 214 & 1039 & 229 & 1178 & 200 & 1095 & 250 & 1158 & 234 & 1214 \\
\hline Romanya & 121 & 471 & 85 & 410 & 143 & 687 & 151 & 664 & 163 & 767 \\
\hline İspanya & 125 & 519 & 156 & 595 & 117 & 527 & 118 & 457 & 117 & 522 \\
\hline G. Afrika & 133 & 348 & 174 & 523 & 206 & 644 & 195 & 599 & 106 & 332 \\
\hline Hollanda & 81 & 243 & 96 & 401 & 71 & 275 & 102 & 284 & 100 & 272 \\
\hline Ukrayna & 146 & 398 & 123 & 353 & 147 & 542 & 138 & 565 & 84 & 493 \\
\hline Fransa & 90 & 254 & 92 & 263 & 84 & 270 & 56 & 166 & 80 & 251 \\
\hline Avusturya & 61 & 420 & 63 & 508 & 72 & 541 & 54 & 398 & 68 & 517 \\
\hline İngiltere & 62 & 324 & 46 & 182 & 69 & 330 & 56 & 309 & 65 & 272 \\
\hline Litvanya & 65 & 158 & 84 & 238 & 70 & 178 & 61 & 186 & 51 & 138 \\
\hline Belçika & 115 & 515 & 71 & 325 & 73 & 368 & 43 & 216 & 41 & 144 \\
\hline İtalya & 14 & 29 & 25 & 58 & 17 & 41 & 26 & 52 & 22 & 45 \\
\hline Rusya & 516 & 1342 & 327 & 1021 & 204 & 716 & 120 & 354 & 8 & 18 \\
\hline Diğer & 1954 & 7141 & 2016 & 7045 & 1929 & 7040 & 2350 & 8297 & 2422 & 9533 \\
\hline Toplam & 10483 & 29951 & 10677 & 32231 & 12256 & 35762 & 12724 & 35831 & 14073 & 40101 \\
\hline
\end{tabular}


Çizelge 22. Türkiye'nin Defne Yaprağı İthalat Miktar ve Değerleri (2012-2016)

Table 22. Turkey's Bay Leaf Import Quantities and Values (2012-2016)

\begin{tabular}{cccc}
\hline Yıl & $\begin{array}{c}\text { Ithalat } \\
\text { Miktarı } \\
\text { (ton) }\end{array}$ & $\begin{array}{c}\text { ithalat } \\
\text { Değeri } \\
(1000 \$)\end{array}$ & $\begin{array}{c}\text { ithalat } \\
\text { Fiyatı }(\$ / \mathrm{kg})\end{array}$ \\
\hline 2012 & 716 & 1274 & 1.78 \\
2013 & 882 & 1538 & 1.74 \\
2014 & 1140 & 1770 & 1.55 \\
2015 & 2302 & 3455 & 1.50 \\
2016 & 1679 & 1872 & 1.12 \\
\hline
\end{tabular}

defne yaprağı ithalatı, 2016 ylında 1679 ton karșilığında 1.87 milyon ABD doları olarak gerçekleșmiștir. Defne yaprağı birim ithalat fiyatı 2012 yılında 1.78 ABD doları/kg iken 2016 yllında 1.12 ABD doları/kg'a düșmüștür (Çizelge 22).

2016 yılında defne yaprağı ithalatında Suriye \%52.83'lük payla ilk sırada, Gürcistan \%43.34'lük payla ikinci sırada yer almaktadır. 2016 yılında Suriye'den 0.39 ABD doları/ kg'dan, Gürcistan'dan 1.84 ABD doları/kg'dan defne yaprağı ithalatı yapılmıștır (Çizelge 23).

Çizelge 23. Türkiye'nin Önemli Ülkelere Göre Defne Yaprağı İthalat Miktarı ve Değeri (2012-2016)

Table 23. Turkey's Import Quantities and Values of Bay Leaf by Major Countries (2012-2016)

\begin{tabular}{lcccccccccc}
\hline & \multicolumn{2}{c}{2012} & \multicolumn{2}{c}{2013} & \multicolumn{2}{c}{2014} & \multicolumn{2}{c}{2015} & \multicolumn{2}{c}{2016} \\
\cline { 2 - 10 } Ülke & $\begin{array}{l}\text { Ithalat } \\
\text { Miktarı } \\
\text { (ton) }\end{array}$ & $\begin{array}{c}\text { ithalat } \\
\text { Değeri } \\
(1000 \$)\end{array}$ & $\begin{array}{c}\text { Ithalat } \\
\text { Miktarı } \\
\text { (ton) }\end{array}$ & $\begin{array}{c}\text { Ithalat } \\
\text { Değeri } \\
(1000 \$)\end{array}$ & $\begin{array}{c}\text { Ithalat } \\
\text { Miktarı } \\
\text { (ton) }\end{array}$ & $\begin{array}{c}\text { Ithalat } \\
\text { Değeri } \\
(1000 \$)\end{array}$ & $\begin{array}{c}\text { ithalat } \\
\text { Miktarı } \\
\text { (ton) }\end{array}$ & $\begin{array}{c}\text { ithalat } \\
\text { Değeri } \\
(1000 \$)\end{array}$ & $\begin{array}{c}\text { Ithalat } \\
\text { Miktarı } \\
\text { (ton) }\end{array}$ & $\begin{array}{c}\text { Ithalat } \\
\text { Değeri } \\
(1000 \$)\end{array}$ \\
\hline Suriye & & & 34 & 59 & 192 & 120 & 671 & 272 & 887 & 348 \\
Gürcistan & 708 & 1217 & 844 & 1470 & 914 & 1589 & 1610 & 3154 & 728 & 1341 \\
Polonya & 4 & 40 & - & - & - & - & - & - & 7 & 36 \\
Diğer & 5 & 16 & 4 & 8 & 34 & 60 & 21 & 29 & 57 & 148 \\
\hline Toplam & 716 & 1274 & 882 & 1538 & 1140 & 1770 & 2302 & 3455 & 1679 & 1872 \\
\hline
\end{tabular}

Çizelge 24. Türkiye'de Adaçayı Üretim Alanı ve Miktarları (2012-2015)

Table 24. Sage Production Area and Amounts in Turkey (2012-2015)

\begin{tabular}{ccc}
\hline Yll & Üretim (ton) & Indeks $(2012=100)$ \\
\hline 2012 & 348 & 100.00 \\
2013 & 328 & 94.25 \\
2014 & 441 & 126.72 \\
2015 & 989 & 284.20 \\
\hline
\end{tabular}

Çizelge 25. Türkiye'nin Adaçayı İhracat Miktar ve Değerleri (2012-2016)

Table 25. Sage Export Quantities and Values of Turkey (2012-2016)

\begin{tabular}{cccc}
\hline YIl & $\begin{array}{c}\text { İhracat } \\
\text { Miktarı } \\
\text { (ton) }\end{array}$ & $\begin{array}{c}\text { İhracat } \\
\text { Değeri } \\
(1000 \$)\end{array}$ & $\begin{array}{c}\text { İhracat } \\
\text { Fiyatı } \\
(\$ / \mathrm{kg})\end{array}$ \\
\hline 2012 & 1490 & 5851 & 3.93 \\
2013 & 1416 & 6336 & 4.47 \\
2014 & 1693 & 6808 & 4.02 \\
2015 & 2070 & 8065 & 3.90 \\
2016 & 2071 & 7651 & 3.69 \\
\hline
\end{tabular}

Türkiye'de tarımı yapılan ve doğadan toplanan adaçayı üretimi incelendiğinde 2012 yılında 348 ton olan adaçayı üretimi 2015 yılında 989 ton olarak gerçekleșmiștir (Çizelge 24). Kültürü yapılan adaçayı üretiminde Karaman, Denizli ve Kütahya illeri en önemli illerdir.

2012 yılında 1490 ton karșılığında 3.93 ABD dolarından 5.85 milyon $A B D$ doları adaçayı ihraç edilirken, 2016 yılında 2071 ton karșilığında 3.69 ABD dolarından 7.65 milyon ABD doları adaçayı ihracatı yapılmıștır (Çizelge 25).

Türkiye'den adaçayı ihracatı yapılan ülkeler arasında ABD, Japonya ve İspanya en önemli ülkeler olarak öne çıkmaktadır. 2016 yılı itibarı ile 2071 ton olan Türkiye adaçayı ihracatında 3089 ton ile ABD ilk sırada yer almaktadır. Adaçayı ihracat fiyatlarına bakıldığında; 2016 ylında en yüksek 5.50 ABD doları/kg'dan Hollanda'ya, en düșük 1.52 ABD doları/kg'dan Fas'a adaçayı ihracatı gerçekleșmiștir (Çizelge 26).

2012 yılı itibarı ile adaçayı ithalat miktarı 844 ton ve ithalat değeri 2.34 milyon $A B D$ doları olup, bu rakamlar 2016 yilında 1446 ton ve 
Çizelge 26. Türkiye'nin Önemli Ülkelere Göre Adaçayı İhracat Miktarı ve Değeri (2012-2016)

Table 26. Turkey's Import Quantities and Values of Sage by Major Countries (2012-2016)

\begin{tabular}{|c|c|c|c|c|c|c|c|c|c|c|}
\hline \multirow[b]{2}{*}{ Ülke } & \multicolumn{2}{|c|}{2012} & \multicolumn{2}{|c|}{2013} & \multicolumn{2}{|c|}{2014} & \multicolumn{2}{|c|}{2015} & \multicolumn{2}{|c|}{2016} \\
\hline & $\begin{array}{l}\text { Ihracat } \\
\text { Miktarı } \\
\text { (ton) }\end{array}$ & $\begin{array}{l}\text { İhracat } \\
\text { Değeri } \\
(1000 \$)\end{array}$ & $\begin{array}{c}\text { İhracat } \\
\text { Miktarı } \\
\text { (ton) }\end{array}$ & $\begin{array}{l}\text { İhracat } \\
\text { Değeri } \\
(1000 \$)\end{array}$ & $\begin{array}{c}\text { İhracat } \\
\text { Miktarı } \\
\text { (ton) }\end{array}$ & $\begin{array}{l}\text { İhracat } \\
\text { Değeri } \\
(1000 \$)\end{array}$ & $\begin{array}{l}\text { İhracat } \\
\text { Miktarı } \\
\text { (ton) }\end{array}$ & $\begin{array}{l}\text { İhracat } \\
\text { Değeri } \\
(1000 \$)\end{array}$ & $\begin{array}{c}\text { İhracat } \\
\text { Miktarı } \\
\text { (ton) }\end{array}$ & $\begin{array}{l}\text { İhracat } \\
\text { Değeri } \\
(1000 \$)\end{array}$ \\
\hline ABD & 160 & 269 & 111 & 322 & 153 & 303 & 116 & 220 & 149 & 260 \\
\hline İspanya & 60 & 199 & 82 & 282 & 53 & 258 & 99 & 345 & 87 & 301 \\
\hline Japonya & 89 & 404 & 110 & 528 & 75 & 430 & 97 & 477 & 81 & 409 \\
\hline Fas & 41 & 60 & 5 & 22 & 38 & 60 & 14 & 20 & 56 & 85 \\
\hline Kanada & 35 & 132 & 30 & 143 & 54 & 228 & 37 & 144 & 52 & 174 \\
\hline Almanya & 18 & 104 & 20 & 123 & 102 & 361 & 73 & 270 & 45 & 210 \\
\hline Avustralya & 17 & 63 & 11 & 57 & 4 & 13 & 19 & 97 & 34 & 153 \\
\hline İngiltere & 44 & 159 & 25 & 124 & 15 & 81 & 27 & 149 & 31 & 166 \\
\hline İtalya & 100 & 354 & 30 & 130 & 23 & 70 & 52 & 175 & 30 & 88 \\
\hline Hollanda & 14 & 103 & 16 & 104 & 19 & 112 & 8 & 47 & 24 & 132 \\
\hline Fransa & 12 & 52 & 4 & 20 & 12 & 75 & 10 & 63 & 8 & 37 \\
\hline Hindistan & 11 & 12 & 1 & 2 & 0.04 & 1 & 19 & 51 & 3 & 7 \\
\hline Diğer & 889 & 3940 & 971 & 4479 & 1145 & 4816 & 1499 & 6007 & 1471 & 5629 \\
\hline Toplam & 1490 & 5851 & 1416 & 6336 & 1693 & 6808 & 2070 & 8065 & 2071 & 7651 \\
\hline
\end{tabular}

Çizelge 27. Türkiye'nin Adaçayı İthalat Miktar ve Değerleri (2012-2016)

Table 27. Turkey's Sage Import Quantities and Values (2012-2016)

\begin{tabular}{cccc}
\hline YII & $\begin{array}{c}\text { Ithalat } \\
\text { Miktarı } \\
\text { (ton) }\end{array}$ & $\begin{array}{c}\text { Ithalat } \\
\text { Değeri } \\
(1000 \$)\end{array}$ & $\begin{array}{c}\text { Ithalat } \\
\text { Fiyatı } \\
(\$ / \mathrm{kg})\end{array}$ \\
\hline 2012 & 844 & 2337 & 2.77 \\
2013 & 489 & 1431 & 2.92 \\
2014 & 993 & 2865 & 2.88 \\
2015 & 838 & 1927 & 2.30 \\
2016 & 1446 & 3009 & 2.08 \\
\hline
\end{tabular}

3.9 milyon ABD dolarına yükselmiștir. Adaçayı birim ithalat fiyatı 2012 yılında 2.77 ABD doları/ kg iken 2016 yılında 2.08 ABD doları/kg'a düșmüștür (Çizelge 27).

Türkiye'nin adaçayı ithalatı yaptığı en önemli ülkeler bașta Arnavutluk olmak üzere, Bosna Hersek ve Karadağ'dır. 2016 yılı itibarı ile 1446 ton olan Türkiye adaçayı ithalatında 1392 ton ile Arnavutluk \%96.29'luk payla birinci sırada gelmektedir (Çizelge 28).

Çizelge 28. Türkiye'nin Önemli Ülkelere Göre Adaçayı İthalat Miktarı ve Değeri (2012-2016)

Table 28. Turkey's Import Quantities and Values of Laurel Foliage by Major Countries (2012-2016)

\begin{tabular}{lcccccccccc}
\hline & \multicolumn{2}{c}{2012} & \multicolumn{2}{c}{2013} & \multicolumn{2}{c}{2014} & \multicolumn{2}{c}{2015} & \multicolumn{2}{c}{2016} \\
\cline { 2 - 10 } Ülke & $\begin{array}{l}\text { Ithalat } \\
\text { Miktarı } \\
\text { (ton) }\end{array}$ & $\begin{array}{c}\text { İthalat } \\
\text { Değeri } \\
(1000 \$)\end{array}$ & $\begin{array}{c}\text { Ithalat } \\
\text { Miktarı } \\
\text { (ton) }\end{array}$ & $\begin{array}{c}\text { Ithalat } \\
\text { Değeri } \\
(1000 \$)\end{array}$ & $\begin{array}{c}\text { ithalat } \\
\text { Miktarı } \\
\text { (ton) }\end{array}$ & $\begin{array}{c}\text { Ithalat } \\
\text { Değeri } \\
(1000 \$)\end{array}$ & $\begin{array}{c}\text { ithalat } \\
\text { Miktarı } \\
\text { (ton) }\end{array}$ & $\begin{array}{c}\text { Ithalat } \\
\text { Değeri } \\
(1000 \$)\end{array}$ & $\begin{array}{c}\text { ithalat } \\
\text { Miktarı } \\
\text { (ton) }\end{array}$ & $\begin{array}{c}\text { Itthalat } \\
\text { Değeri } \\
(1000 \$)\end{array}$ \\
\hline Arnavutluk & 753 & 2104 & 402 & 1181 & 738 & 2125 & 714 & 1625 & 1392 & 2895 \\
Bosna Hersek & 46 & 128 & 37 & 105 & 197 & 566 & 83 & 193 & 34 & 69 \\
Karadağ & - & - & 36 & 105 & 57 & 164 & 24 & 52 & 14 & 29 \\
Diğer ülkeler & 7 & 29 & - & - & 1 & 10 & 17 & 56 & 5 & 15 \\
Lübnan & 30 & 67 & - & - & - & - & - & - & 1 & 2 \\
Mısır & 9 & 9 & 14 & 39 & - & - & - & - & - & - \\
\hline Toplam & 844 & 2337 & 489 & 1431 & 993 & 2865 & 838 & 1927 & 1446 & 3009 \\
\hline
\end{tabular}




\section{Sonuç ve Öneriler}

Türkiye, tıbbi ve aromatik bitkiler üretimi ve ihracatında dünyanın en önemli ülkelerinden birisi olmasına rağmen ihracat miktar ve değerini istenilen düzeylerde arttıramamıștır. 2016 yılında 158 milyon ABD doları tıbbi bitki ihracatı gerçekleștirilirken, 41 milyon ABD doları tıbbi bitki ithalatı yapılmıștır. 2016 yılında tıbbi ve aromatik bitkilerde inracatın ithalatı karșılama oranı \%385'dir. Dıș ticaret verileri incelendiğinde; yıllara göre değișen miktarlarda olmakla birlikte, ihracatı yapılan tıbbi ve aromatik bitkilerin bazılarının aynı zamanda ithal edilen ürünler içerisinde olduğu da görülmektedir. Elbette, bunun en önemli sebeplerinden birisi sektörde faaliyet gösteren aracı ve firmaların ticari tercihleri olmakla birlikte, Türkiye'de tıbbi ve aromatik bitkilerin ișlenmesi, tali ürünlerinin satıșa hazır hale getirilmesi vb. faaliyetlerin henüz istenen seviyede olmaması nedeniyle, bazı tıbbi ve aromatik bitkiler hem ihracat hem de ithalata konu ürünler olarak görülebilmektedir.

Türkiye'de tıbbi amaçlar için kullanılan bitki türlerinden yaklașık 200 tıbbi bitkinin ihracat potansiyelinin olmasına rağmen ancak 70-100 arası tür ihraç edilmektedir (Bașer 2000). Ancak, bu türlerin büyük çoğunluğunun ne olduğu istatistiklerde yer almamaktadır. En çok ihracatı yapılanlar dıșındaki tıbbi bitkiler istatistiklerde "diğerleri" faslında yer almaktadır. Bu nedenle, Türkiye'den ihracatı yapılan tıbbi ve aromatik bitkilerin tam listesine ulașılamamaktadır (Öztürk ve ark. 2012). Türkiye'de yetiștiriciliği yapılan ve doğadan toplanan tıbbi ve aromatik bitkilerin toplayıcı, aracı, ihracat firmaları ve ilgili devlet kurumlarıyla birlikte çalıșlarak tamamının tespitinin yapılıp tam listesinin hazırlanması ve bir veri tabanı olușturulması gerekmektedir (Faydalıoğlu ve ark. 2011). Tam listesi hazırlanan tıbbi ve aromatik bitkilerin olușturulan veri tabanında doğadan toplanan ve tarımı yapılan tıbbi ve aromatik bitkilerin istatistiklerinin ayrı ayrı verilmesi ve veri tabanının sürekli güncellenmesi önemlidir.

Diğer taraftan, Türkiye'nin tıbbi bitki ihracatının büyük bir kısmı ișlenmemiș ürünlerden olușmakta olup ülke ekonomisi açısından düșük katma değer yaratmaktadır. Temizleme, ayıklama, tasnifleme, toptan ve perakende paketleme ișlemleri sınırlı sayıda baharat ve çay üretiminde uygulanmaktadır (Binici 2002). Doğadan toplanan ve tarımı yapılan tıbbi ve aromatik bitkilerin standardizasyonunun sağlanması ve ișlenmesi, Türkiye'nin ihracat miktarını yükseltecektir. Tıbbi ve aromatik bitkilerin ișleme ve paketleme alanında kullanılacak makinelerin üretilmesi ya da yurtdıșından temin edilmesi ile, bu bitkilerden elde edilen katma değerde artıș sağlanmalıdır (Metin ve ark. 2012).

Tıbbibitki ihracatında Türkiye'nin pazar payını artırmak için, ekonomik değeri yüksek olan bitkilerin kültüre alınması ve ıslahı sağlanmalıdır (Yücer ve Altıntaș 2012). Türkiye'de ekilen bitki türlerinde tescilli çeșit sayısı çok azdır. Son yıllarda keten, hașhaș, anason, kișniș, çemen, kekik, adaçayı, fesleğen, tere, roka gibi bitkilerde bazı çeșitler tescil edilmiș veya tescil çalıșmaları bașlatımıștır (Arslan ve ark. 2005). Türkiye'nin tıbbi bitki inracatının artmasını sağlamak için tıbbi ve aromatik bitkilerin kültüre alınması ve ıslah çalıșmalarının yapılması gerekmektedir. Bununla birlikte, çeșit geliștirme çalıșmalarının yapılması önem arz etmektedir.

Ayrıca, tıbbi ve aromatik bitkilerin doğadan toplanması ve üretilmesi ile ilgili mevzuat eksikliklerinin giderilmeli ve toplayıcılara doğanın tahrip edilmesini ve tıbbi bitki türlerinin neslinin tehlikeye girmesini engellenmek amacıyla eğitimler verilmelidir.

Bunların dıșında, sektörün sorunlarının çözümü ve daha ileriye tașınması için ve daha etkin sonuçlar elde edilmesi için, tıbbi bitki alanında yapılan çalıșmalarda tarım ekonomistleri, agronomistler, tıp doktorları ve eczacılar ortak çalıșmalar yapmalıdır.

\section{Kaynaklar}

Arslan N., Baydar H., Süleyman K., Karık Ü., Șekeroğlu N. ve Gümüșçü A., 2015. Tıbbi Aromatik Bitkiler Üretiminde Değișimler ve Yeni Arayıșlar, Türkiye Ziraat Mühendisliği VIII. Teknik Kongresi, 12-16 Ocak 2015, Ankara, s. 483-507 Aydın E., Yurum Ç., Kevseroğlu K. ve Seyis F., 2014. Doğadan Yoğun Olarak Toplanan Pazar Payı Yüksek Olan Önemli Tıbbi ve Aromatik Bitkilerin Risk Durumları, 23-25 Eylül 2014, Yalova, Bildiriler Kitabı, s: 281-286

BAKA, 2012. Tıbbi ve Aromatik Bitkiler Sektör Raporu, Batı Akdeniz Kalkınma Ajansı, Aralık, 2012 
Bașer K.H.C., 2000. Sustainable Wild Harvesting of Medicinal and Aromatic Plants: An Educational Approach, Harvesting On Non-Wood Forest Products, Seminar Proceedings, Menemenİzmir, Turkey

Bașer K.H.C., 2001. Her Derde Deva Bir Bitki Kekik. Bilim ve Teknik Dergisi 402:74-77

Bașer K.H.C., 2014. "Türkiye'nin Önemli Tıbbi ve Aromatik Odun Dıșı Orman Ürünleri”, Tıbbi ve Aromatik Bitkilerin Eczacılık ve Ormancılıktaki Önemi Çalıștayı, İnönü Üniversitesi, Eczacılık Fakültesi, Elâzığ Orman Bölge Müdürlüğü, Malatya

Bayramoğlu M.M., Toksoy D. ve Șen G., 2009. "Türkiye'de Tıbbi Bitki Ticareti", II. Ormancılıkta Sosyo- Ekonomik Sorunlar Kongresi, Isparta, 19-21 Șubat 2009, s.89-98

Binici A., 2002. Baharat Değerlendirme Raporu. Orta Anadolu İhracatçı Birlikleri Genel Sekreterliği, s.1-37

Faydaoğlu E. ve Sürücüoğlu M.S., 2011. Geçmișten Günümüze Tıbbi ve Aromatik Bitkilerin Kullanılması ve Ekonomik Önemi. Kastamonu Üniversitesi Orman Fakültesi Dergisi, 11(1):5267

Metin İ., Güngör H. ve Çolak Ö.F., 2012. Bazı Tıbbi ve Aromatik Bitkilerin İhracatı ve İthalatı, Tıbbı ve Aromatik Bitkiler Sempozyumu 13-15 Eylül 2012 Tokat, s. 326-333
Özgüven M., Sekin S., Gürbüz B., Șekeroğlu N., Ayanoğlu F. ve Ekren S., 2005. Tütün, tıbbi ve aromatik bitkiler üretimi ve ticareti. Türkiye Ziraat Mühendisliği VI. Teknik Kongresi, 1, s.481-501

Öztürk M., Temel M. ve Tınmaz A.B., 2014. Türkiye'de Kekik Üretim ve Pazarlaması, II. Tıbbi ve Aromatik Bitkiler Sempozyumu 23-25 Eylül 2014, Yalova

Öztürk M., Temel M., Tınmaz A.B. ve Kil L., 2012., Tıbbi ve Aromatik Bitkilerin Dıș Ticaretimizdeki Yeri, Tıbbı ve Aromatik Bitkiler Sempozyumu 13-15 Eylül 2012 Tokat, s.33-44

TUiK, 2016, Türkiye İstatistik Kurumu, http://www. tuik.gov.tr [Erișim: Mart 2017]

UNCTAD, United Nations Conference on Trade and Development, http://unctad.org [Erișim: Mart 2017]

Yoğunlu A., 2011. Tunceli Ekonomik Değeri Olan Bitkiler Raporu, Sektörel Araștırmalar Serisi-5, Fırat Kalkınma Ajansı, 2011

Yücer A. ve Altıntaș G., 2012. Türkiye'nin Tıbbi ve Aromatik Bitkiler Dıș Ticareti, Tıbbı ve Aromatik Bitkiler Sempozyumu 13-15 Eylül 2012 Tokat, s.55-63 